\title{
The influence of electronic word-of-mouth adoption on brand love amongst Generation $Z$ consumers
}

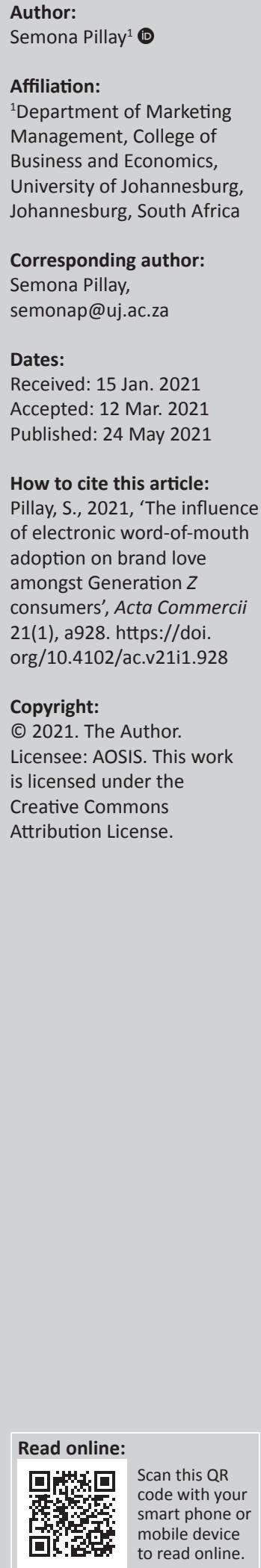

Orientation: The study investigated the influence of electronic word-of-mouth (eWOM) adoption on brand love amongst Generation $Z$ consumers in South Africa that will enable marketers to improve their brand love strategies amongst this generation.

Research purpose: The study used the information adoption model to investigate the impact of eWOM adoption on brand love amongst Generation $Z$ consumers.

Motivation for the study: This study adds to the limited body of literature on Generation $Z$ consumers in emerging markets. It examines drivers of online purchase decisions of Generation $\mathrm{Z}$ consumers, such as eWOM adoption and brand love.

Research design, approach and method: The study followed a descriptive quantitative approach. Data were obtained through structured questionnaires from Generation Z consumers. Non-probability, purposive sampling was used to select the sample. Data were captured, coded and cleaned using Statistical package for the social sciences (SPSS) version 25, yielding 284 usable questionnaires. Apart from descriptive statistics, confirmatory factor analysis was used to test the validity of the constructs obtained from previously developed scales through convergent and discriminant validity. The reliability of the constructs was tested using Cronbach's alpha and composite reliability. The conceptual model was tested using Structural Equation Modelling and the hypotheses were analysed using path modelling in Analysis of moment structures (AMOS) version 25.

Main findings: The results revealed a positive, weak relationship between eWOM adoption and brand love. Argument quality had a strong, positive influence on information usefulness, which in turn, had a strong, positive influence on eWOM adoption.

Practical/managerial implications: Marketers can use the findings of this study to target Generation $Z$ consumers in emerging markets more effectively by sharing quality, authentic content through Facebook and Instagram to encourage eWOM adoption and somewhat affect brand love.

Contribution/value-add: This study adds to the limited body of knowledge on Generation Z consumers in emerging markets. It elucidates how marketers can encourage eWOM adoption amongst this generation, thereby leading to brand love, to some extent.

Keywords: brand love; eWOM; generation Z; information adoption model; South Africa.

\section{Introduction}

Emerging markets are developing countries whose economies are growing rapidly (AmankwahAmoah, Boso \& Debrah, 2018). The main aim of an emerging market is to advance its economy (Saksiriruthai 2019). Emerging markets are essential for the global economy because they comprise $80 \%$ of the global population and $70 \%$ of total global gross domestic product (GDP) (Corporate Finance Institute 2021). In general, emerging markets experience rapid growth, high productivity levels and rising standards of living (Amankwah-Amoah et al., 2018). However, there is a high degree of instability and volatility in these markets, which are susceptible to inflation, price changes in commodities and fluctuating currencies and interest rates (Tsagkanos, Siriopoulos \& Vartholomatou 2019). Amadeo (2020) inferred that instability and volatility increase the risk of doing business with emerging markets. However, for most foreign investors, higher risks equate to higher returns, which increase the attractiveness of such markets. Globally, the top five emerging markets are Brazil, Russia, India, China and South Africa (BRICS) (Asongu, Akpan \& Isihak 2018). However, numerous other emerging markets, especially in Africa, have been identified to provide major opportunities for foreign investors (Amankwah-Amoah, Boso \& Debrah 2018).

South Africa is one of the fastest-growing economies on the continent (Asongu et al. 2018). It has high market potential, a well-established democracy, macro-economic stability, a stable business 
climate and a strategic geographical location, making it attractive to foreign investors and international brands (Asongu et al. 2018; Masipa 2018; Meyer \& Habanabakize 2018). A report by the United Nations (World Network 2019) found that foreign direct investment in South Africa increased from US\$1.3 billion in 2017 to US\$7.1 billion in 2018 (a massive increase of $446 \%$ ), confirming the attractiveness of South Africa as an emerging market. Despite large disparities between consumer income groups and high levels of unemployment and poverty, South Africa is the second largest e-commerce market in Africa and one of the most developed markets with regard to smartphone penetration and telecommunications infrastructure compared with other emerging African markets (Chetty et al. 2018; Tandwa 2020). South African e-commerce has grown because of an improved telecommunications infrastructure, reduced data costs and improved digital literacy, especially amongst Generation Z consumers and is the focus of this study (Chetty et al. 2018; Tandwa 2020).

Generation Z is a demographic cohort comprising individuals born between 1995 and 2010 (Loveland 2017). Debb, Schaffer and Colson (2020:44) posited that Generation Z consumersalso called 'digital natives'-were born into a digital age in which internet and mobile technologies were already in place. Generation $Z$ consumers are thus described as the most technologically savvy generation in relation to their predecessors (Loveland 2017; Thomas, Kavya \& Monica 2018). The most commonly used technological device amongst Generation $Z$ consumers is the smartphone (Ayuni 2019; Zhitomirsky-Geffet \& Blau 2016). Globally, Generation $\mathrm{Z}$ consumers value maintaining social connections, as well as interacting and engaging with each other. Alanko (2018) and Duffett (2017) explained that interaction and engagement are key drivers for sharing electronic word-of-mouth (eWOM) reviews-the focus of this study. In South Africa, Generation $Z$ consumers share similar needs and characteristics with the global cohort. However, they are significantly affected by external environmental factors.

In South Africa, many Generation Z consumers are cautious about the brands they purchase (Deloitte 2014; Peyper 2017). These consumers are fickle and often switch to brands that offer them the best value for money (Hanbury 2019; Priporas, Stylos \& Fotiadis 2017). They are thus less brand loyal than their predecessors. Ordun (2015) reinforced that these consumers are obsessed with value for money. Despite being known for brand switching, South African Generation Z consumers prefer brands that reflect their values and understand them as consumers (Jenkins 2019). These brands should also be authentic and genuine and should resonate with Generation $Z$ consumers (Hanbury 2019; Munsch 2021). This increases the likelihood that Generation $Z$ consumers will become emotionally attached to such brands and love them (Kowalczyk \& Pounders 2016; Mody \& Hanks 2018; Skeldon 2019). Many consumers share their love for a brand on social media through eWOM (Bigne et al. 2019; Ruiz-Mafe \& Veloutsou 2017).

Generation Z represents one-third of South Africa's population (Ronnie 2018). Of South Africa's entire population, approximately half lives in poverty. This implies that a large proportion of Generation $Z$ consumers live in poverty and have limited disposable income (Fourie 2017; Gomo 2019). Not only that, South African Generation $Z$ consumers face high unemployment rates, which further sap disposable income (Jordaan 2019). This implies that Generation $Z$ consumers are selective about the brands they choose to purchase. However, many are brand- and status-conscious and their preference for international brands is higher than for local brands, which supports developed market economies rather than emerging market economies (Cronje, Jacobs \& Retief 2016; Pavlić \& Vukić 2019). South African Generation Z consumers' preference for international brands stem from the greater exposure of these brands, in comparison to local brands, on social media sites, which are commonly accessed using smartphones (Ayuni 2019; Cronje et al. 2016). Despite their increased use of smartphones, only 30\% South African Generation $Z$ consumers make brand-related purchases online as compared with the global average of $61 \%$ (Fourie 2017; Stastista 2018; Thompson 2017). Other factors that affect South African Generation Z consumers' online purchases include cybercrime, the inability to afford data and an inadequate telecommunications infrastructure in rural areas (Fourie 2017; Killian, Kabanda \& Kilian 2017; Malapane 2019). Despite low online purchase statistics, $76 \%$ of Generation Z consumers in South Africa read online (eWOM) reviews that can influence their shopping decisions (Thompson 2017).

Over the past 10 years, eWOM has grown in popularity, becoming a significant driver of many purchase decisions (Prasad, Gupta \& Totala 2017). Erkan and Evans (2016) attributed the growth in popularity of eWOM to the development of social media, which allow consumers to interact and engage with one another. Through that interaction and engagement, consumers become informed about products and brands through eWOM reviews posted by fellow consumers on social networks (Narangajavana et al. 2017; Shan \& King 2015). Generation $Z$ consumers, in particular, prefer to obtain eWOM reviews about brands from social media and influencers (RiivitsArkonsuo \& Leppiman 2015). These consumers appreciate the authenticity and honesty associated with eWOM reviews on social media and rely on this information to inform their online purchase decisions (Cruz 2016). Jenkins (2019) added that authentic, honest brands that are aligned with Generation $Z$ consumers' values lead to brand love. This fosters customer retention and loyalty, which for many brands is the most highly desired outcome (Huang 2017; Islam \& Rahman 2016; Skeldon 2019). To investigate the influence of eWOM on consumer decision-making, Sussman and Seigal (2003) developed the information adoption model (IAM).

The IAM is used in this study to investigate the influence of eWOM on brand love. Many prior studies, including those of Charo et al. (2015) and Zhu, Chang and Luo (2016), have explored the impact of the IAM on consumer decisionmaking by adding behavioural constructs such as purchase intention and purchase decision. However, few have determined the effect of the IAM constructs on brand-specific 
consumer behaviour. Understanding the influence of IAM on brand-specific behaviour is crucial in relation to Generation $\mathrm{Z}$ consumers, who show little loyalty towards brands, yet display high levels of brand love (Bıçakcıŏlu, İpek \& Bayraktaroğlu 2018; Ordun 2015). Because of the reliance of these consumers on social media and eWOM to obtain brandrelated information, it is important to identify whether eWOM adoption affects brand love. This is because brand love drives many purchase decisions of Generation $Z$ consumers (Ordun 2015). A report by Euromonitor (2018) predicted that Generation $\mathrm{Z}$ consumers will become the largest online consumer market. However, in South Africa, prior research on this market segment is scant.

\section{Problem statement}

The research problem is threefold: (1) There is a lack of research on Generation $Z$ consumers in emerging markets, (2) Generation $Z$ consumers in South Africa often switch brands and (3) South African Generation $Z$ consumers prefer to accept information through eWOM; however, marketers are unaware of the full extent of the influence of eWOM on Generation Z consumers.

Most prior research on Generation Z consumers, eWOM and brand love has been conducted in developed markets, which differ significantly from those of emerging markets (Mehta \& Dixit 2016). An in-depth understanding of consumers in emerging markets is needed, given the attractiveness of these markets for international trade, including their booming economies, high growth potential and increasing demand for products (Aregbeshola 2018). Currently, most market research is focussed on millennials; however, Duffett (2020) stated that Generation $Z$ consumers have entered the workforce and have increasing disposable income to purchase brands. Hodgson (2018) added that the largest consumer cohort in emerging markets is projected to be Generation $Z$ consumers; however, research in this field is scant, particularly South Africa. South African Generation $Z$ consumers are expected to become the largest online market by 2030 because of their entrepreneurial predisposition (Diaz 2019; Stats SA 2019b). South Africa is classified as an emerging market as it has the fastest-growing economy and the secondlargest e-commerce market in Africa (Asongu et al. 2018; Masekesa 2020). E-commerce in South Africa surpasses most other emerging markets in Africa, with online sales accounting for $50 \%$ of total sales nationally, making it an attractive market for international trade and brands (Kemp 2019; Mou et al. 2017). Kemp (2019) noticed that one of the most popular e-commerce activities is searching for information, carried out by $88 \%$ of South African consumers.

South Africans in general, tend to use social media as a means of obtaining information (Kemp 2019). The popularity of social media in South Africa has grown rapidly over the last 5 years because of increasing smartphone purchases, an improved telecommunications infrastructure and better digital literacy skills, particularly amongst Generation Z consumers (Chetty et al. 2018;Poushter, Bishop \& Chwe
2018;Tandwa 2020). These consumers accept and adopt eWOM reviews of brands by fellow consumers and influencers, as they perceive this content to be more credible than marketer-generated advertisements and content (RiivitsArkonsuo \& Leppiman 2015). Furthermore, many Generation $Z$ consumers 'follow' and 'like' brand-specific social media pages that they feel are genuine and authentic, which thereby become drivers of brand love (Hanbury 2019; Munsch 2021). However, despite the prevalence of brand love amongst Generation Z consumers, many of them switch between brands that offer the best value for money (Priporas et al. 2017). Brand switching presents challenges for marketers, including low customer retention rates, negative effect on customer satisfaction and brand love and lack of brand loyalty (B1çakcıŏlu et al. 2018; Rizwan et al. 2013). Brand switching is more prevalent in South Africa, where consumers are faced with the threat of unemployment, which leads to less disposable income. It is therefore more challenging for marketers to retain Generation Z consumers (Stats SA 2019a; World Bank 2019). To prevent such brand switching, marketers should strive to establish brand love through eWOM as brand love drives Generation Z consumers' brand-related purchases and brand loyalty (Bıçakcıoğlu et al. 2018; Verma 2021).

Numerous studies have examined eWOM through the prism of the IAM (Erkan \&Evans 2018; Hussain et al. 2016; Phung et al. 2020). These studies demonstrated that source credibility, argument quality and information usefulness are positively associated with eWOM adoption. Charo et al. (2015), Erkan and Evans (2016) and Rahmi, Sekarasih and Sjabadhyni (2016) have extended the IAM by including other behavioural outcomes, such as purchase intention and purchase decision. However, very few studies have focussed on brand-specific behavioural outcomes such as brand love. A study of the influence of eWOM on brand-specific outcomes such as brand love amongst South African Generation $Z$ consumers would provide useful insights for marketers, allowing them to effectively retain these customers and prevent brand switching.

The aim of this study is to add to the limited body of literature on Generation Z consumers in South Africa and to apprehend important drivers of eWOM adoption and brand love using the IAM.

\section{Theoretical framework}

The theoretical framework outlines the key concepts and constructs to be investigated in this study. These concepts and constructs, which identify the determinants of eWOM using the IAM, have been adopted from Erkan and Evans (2016), Shamhuyenhanzva et al. (2016) and Sussman and Seigal (2003). These studies have demonstrated that constructs of the IAM-source credibility, argument quality, information usefulness, information adoption-are determinants of eWOM; they have therefore been used in this study. Other studies, such as those of Biçakcioğlu et al. (2018) and Vernuccio et al. (2015), have discovered that positive eWOM is an outcome of brand love, which implies that consumers 


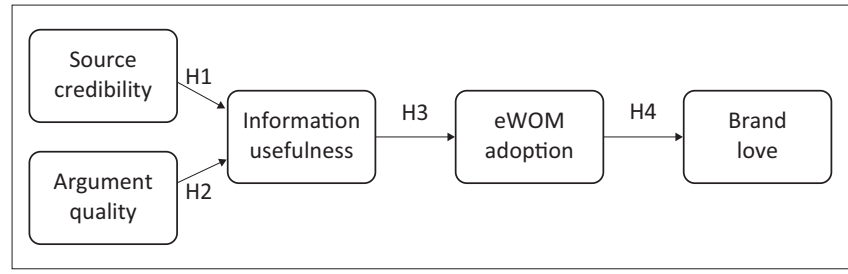

eWOM, electronic word-of-mouth.

FIGURE 1: Proposed theoretical model.

must first love the brand before they generate positive eWOM. However, the present study investigates the opposite view-that is, whether eWOM influences brand love. The motivation behind this aim is the highly interactive nature of the internet, which allows consumers to generate their own content (Zahra, Qayyum \& Rashid 2019). This content is often generated by consumers and therefore outside the control of the brand and hence, it may influence consumers' love for the brand (Bhandari, Rodgers \& Pan 2021). Brands should therefore identify which of the IAM constructs affect eWOM and use these constructs to positively influence eWOM to increase brand love amongst consumers. The proposed relationship between the constructs is presented in Figure 1.

\section{Electronic word-of-mouth}

Electronic word-of-mouth or eWOM refers to the sharing of positive or negative feedback about a product or brand on the internet (Ferreira \& Barbosa 2017). The rise of eWOM has been attributed to the development of Web 2.0, which enables internet users to generate their own content, also known as 'user-generated content' or UGC (Kim \& Johnson 2016; Zahra et al. 2019). Through UGC shared via social networks, consumers are able to post reviews and make recommendations about products and services (Ferreira \& Barbosa 2017; Kim \& Johnson 2016). Facebook is the most widely used social network amongst South African consumers of all ages, with 17.6 million users. This platform is also the most popular amongst Generation $Z$ consumers (Ndyave \& Kyobe 2017; Statista 2020). One of the top three reasons that South African consumers use Facebook is to search for product and brand information (Kemp 2019). Consumers prefer to obtain information from social networks, which are perceived as coming from fellow consumers who have had some sort of prior experience with the given brand (Shamhuyenhanzva et al. 2016; Zahra et al. 2019). Moran and Muzellec (2017) asserted that many consumers perceive this information as more credible and are thus more likely to believe it. Consumers who believe eWOM reviews, often rely on that information to make their purchase decisions (Erkan \& Evans 2016; Shamhuyenhanzva et al. 2016).

\section{Information adoption model}

The IAM is derived from the technology acceptance model (TAM) and the elaboration likelihood model (ELM) (Wang 2016). According to Erkan and Evans (2016), the TAM was originally developed by Davis (1989), based on the theory of reasoned action (TRA). The difference between the two is that the TAM focusses more on information systems, whilst the TRA emphasises behavioural theories. Davis (1989) explained that the TAM includes two main constructs: perceived usefulness and perceived ease of use. These predict the consumer's attitude towards accepting technologies. For this reason, the TAM has been used in numerous studies to explain the adoption of information in relation to eWOM (Chong et al. 2018; Yang 2017; Zeng \& Seock 2019). Despite its widespread use, the TAM has been criticised for disregarding the social process of information development and implementation, particularly because eWOM is generated by individuals and not by computers (Erkan \& Evans 2016). Furthermore, Yang (2017) maintained that the TAM focusses on usage and neglects the relationship between intention and behaviour. To combat the limitations of the TAM, the IAM was developed by Sussman and Siegal (2003) to investigate how individuals adopt, internalise and use information. The IAM includes elements from the ELM, which postulates that individuals are influenced by two routes: central and peripheral (Wang 2016). The central route refers to the principal message, whereas the peripheral route focusses on the aspects indirectly related to the principal message (Zhang et al. 2017).

The IAM consists of four constructs: (1) source credibility, (2) argument quality, (3) information usefulness and (4) information adoption (Sussman \& Siegal 2003; Wang 2016). The model demonstrates that if source credibility is high and perceived argument quality is good, information is perceived to be useful and is therefore more likely to be adopted (Sussman \& Siegal 2003). The IAM is selected for this study as it appropriately explains information adoption on computer-mediated communication platforms-in this case, social networks. To validate the appropriateness of the IAM, numerous studies (Erkan \& Evans 2018; Hussain et al. 2016; Phung et al. 2020), have confirmed that the IAM's four constructs are positively associated with eWOM. Prior studies conducted by Charo et al. (2015) and Zhu et al. (2016) have expanded the IAM model to include behavioural outcomes such as purchase intention and purchase decision. Only a limited number of studies have focussed on brandspecific outcomes such as brand love (Bıçakcioğlu et al. 2018; Verma 2021). Understanding brand love is key to establishing brand loyalty amongst Generation $Z$ consumers, who tend to be less brand-loyal (Mody \& Hanks 2018). Therefore, this study uses the four existing IAM constructs but expands the model to include brand love. Each of the proposed model's constructs is discussed here.

\section{Source credibility}

Source credibility refers to the source of the message being perceived as believable, trustworthy and reliable (O'Reilly et al. 2016). Source expertise and source trustworthiness are essential to source credibility (Moran \& Muzellec 2017; Shamhuyenhanzva et al. 2016). Source expertise refers to the source having experience with a brand and being knowledgeable about it (Ismagilova et al. 2019). Source trustworthiness is the degree to which a source is seen as 
being honest, sincere and fair (Rahmi et al. 2016). Consumers tend to be more receptive and accepting of information when they perceive the source to be trustworthy (Moran \& Muzellec 2017; O'Reilly et al. 2016; Sirithanaphonchai 2017). Generation $\mathrm{Z}$ consumers tend to trust the expertise of influencers on social media, whose information they perceive as authentic and credible (Duffett 2020; Riivits-Arkonsuo \& Leppiman 2015). Prior studies from developed markets report that most Generation $Z$ consumers' purchase decisions are positively influenced by eWOM because of enhanced trust, credibility and authenticity (Bruns 2018; Florenthal 2019; Kowalczyk \& Pounders 2016).

In relation to the IAM, greater perceived source credibility positively influences the usefulness of information (Sussman \& Siegal 2003). Erkan and Evans (2016) and Hussain et al. (2016) revealed that source expertise positively affects information usefulness. Sirithanaphonchai (2017) noticed that source expertise does not have a positive, significant impact on information usefulness, but that source trustworthiness does. These studies were conducted in developed markets; the impact of source credibility on information usefulness and eWOM adoption amongst Generation $Z$ consumers in South Africa is yet to be explored. The first hypothesis as outlined in Figure 1, therefore, proposes that source credibility of eWOM reviews has a positive, significant influence on information usefulness.

\section{Argument quality}

Argument quality is the degree to which consumers perceive information to be valuable and persuasive (Zhang \& Barnes 2019). Prior studies have identified three main drivers of argument quality: timeliness, usefulness and accuracy (Charo et al. 2015; Tseng \& Wang 2016). Timeliness refers to the information being recent and up-to-date. When searching for online comments and reviews on social media, consumers perceive current information to be of greater value (Tong, Bao \& Chong 2016). Accuracy has a positive, significant impact on argument quality and information usefulness (Charo et al. 2015; Zhang \& Barnes 2019). It refers to the correctness and reliability of the information conveyed (Fanoberova \& Kuczkowska 2016). The usefulness of information also positively influences argument quality insofar as the relevance of the information addresses consumers' needs (Bao \& Huang 2018). Generation Z consumers appreciate constantly updated information (timeliness) that is not overly polished and is as authentic (accurate) as possible (Viertola 2018). Electronic word-ofmouth reviews of a higher argument quality influence information usefulness (Charo et al. 2015; Hussain et al. 2016), thereby supporting the second hypothesis - that argument quality of eWOM reviews has a positive, significant influence on information usefulness.

\section{Information usefulness}

Sussman and Siegal (2003) affirmed that when the source of information is perceived to be credible and the quality of the argument is perceived to be good, information usefulness is enhanced. Erkan and Evans (2016) proposed that the usefulness of information determines whether it addresses consumers' needs successfully. If consumers see information as useful, they are more likely to accept the information from an eWOM review (Hussain et al. 2016). Prior studies have confirmed this relationship (Erkan \& Evans 2016; Hussain et al. 2016; Moran \& Muzellec 2017) and form the basis for the third hypothesis in this study - that information usefulness has a positive, significant influence on eWOM adoption.

\section{Information adoption}

Information adoption is defined as accepting and using information to influence a particular behavioural outcome (Sussman \& Siegal 2003). Several studies have explored the impact of information adoption on behavioural outcomes, such as purchase intention and purchase decision (Charo et al. 2015; Erkan \& Evans 2016; Rahmi et al. 2016). In most cases, information adoption has a positive, significant effect on purchase intention and purchase decision. Nevertheless, very few studies have emphasised the brand-specific behavioural outcomes of brand engagement and brand loyalty. These studies have demonstrated that information adoption positively influences brand image and brand loyalty (Huang 2017; Islam \& Rahman 2016). Most Generation $\mathrm{Z}$ consumers are less likely to be loyal to brands unless they are authentic and genuine and reflect the consumers' own values (Djafarova \& Bowes 2021; Hanbury 2019). Authenticity is more likely to lead to brand love-a key driver of brand loyalty (Mody \& Hanks 2018). Brand love is the outcome of interest in this study and the relationship between information adoption and brand love is denoted by hypothesis four - that eWOM adoption has a positive, significant influence on brand love.

\section{Brand love}

'Brand love' refers to the emotional attachment of a satisfied consumer to a brand (Bagozzi, Batra \& Ahuvia 2017; Karjaluoto, Munnukka \& Kiuru 2016). Brand love stems from positive emotions and experiences with a brand that creates positive attitudes towards that brand (Huang 2017; Taute et al. 2017). Having a positive attitude towards a brand encourages consumers to build long-term relationships with it and increases the likelihood that they will speak about the brand (Karjaluoto et al. 2016; Taute et al. 2017). Prior studies have proven that consumers who love their brands will share their positive evaluations through eWOM (Ismail \& Melewar 2015; Karjaluoto et al. 2016). Generation $Z$ consumers prefer to receive information about brands through eWOM as they perceive this information to be genuine and authentic (Jenkins 2019). Having authentic information and feeling that the brand is genuine leads Generation $Z$ consumers to love the brand (Mody \& Hanks 2018). Other important outcomes of brand love include brand loyalty, brand prestige and brand trust (Bıçakcıŏlu et al. 2018; Kazmi \& Khalique 2019). Despite the numerous studies on the impact of eWOM and brand love, most have been conducted in developed markets 
and very few focus on Generation $Z$ consumers. Studies by Karjaluoto et al. (2016) and Melewar (2015) reviewed brand love as an antecedent of WOM, whilst this study provides insight into brand love as an outcome of eWOM. The reason for investigating eWOM as an antecedent of brand love is to assist marketers to stimulate postive eWOM to create brand love, which may lead to brand loyalty and retention. This is especially important in South Africa as brand switching is high amongst Generation Z consumers (Hanbury 2019; Priporas et al. 2017).

Based on the given discussion, the hypotheses are presented in Figure 1.

\section{Research method and design}

This study followed a positivist approach to obtain objective, quantifiable and observable data. Through a deductive approach, this study examined the influence of eWOM adoption on brand love. A descriptive, quantitative research design was selected to gain insight into the influence of the four IAM constructs on brand love. These constructs have been previously investigated in several empirical studies, including those by Charo et al. (2015), Erkan and Evans (2016) and Rahmi et al. (2016), demonstrating that IAM influences behavioural outcomes such as purchase intention and purchase decision. However, the influence on brand love for Generation $Z$ consumers in South Africa is yet to be discovered. Because there are numerous quantitative studies on IAM and eWOM, a descriptive rather than exploratory approach was deemed more suitable for this study, thus it used already developed scales. Hair et al. (2015) stated that this type of research design is selected to gather large amounts of data to establish key patterns and statistical relationships. This ensures that the views of the population at large are accurately reflected.

\section{Sampling}

A non-probability, purposive sampling method was used to select the study sample. Purposive sampling is the most appropriate sampling technique to use when the scope of the study requires specific criteria to be met (Hair et al. 2015). The scope of this study jusitfied the need for specific criteria. The research topic is based on eWOM amongst Generation $Z$ consumers in South Africa, therefore the respondents had to meet three main criteria. The first criterion required respondents to be between the ages of 18 and 25 years, as this is the age range of Generation $Z$ consumers. Any respondent who did not fall within this age range was deemed unsuitable to complete the questionnaire. For the second criterion, it was discovered that most Generation $Z$ consumers access eWOM via social media and to access eWOM on these social networks requires consumers to have a social media profile. The third criterion was for consumers to have seen an online comment or online review about a brand in the 6 months before the data were collected to ensure that they engaged with some form of eWOM. The sample was moreover selected from a highly populated and urbanised city in South
Africa with the largest number of Generation $Z$ consumers (StatsSA 2018). The selected city is also the technology hub of South Africa and most individuals living in this city have access to the internet (StatsSA 2018). In total, the sample consisted of 300 individuals who met the three criteria. The decision on sample size was based on the rule of thumb for conducting structural equation modelling: $N \geq 100$ (In'nami \& Koizumi 2013). Moreover, Kyriazos (2018) posited that general goodness of fit indices are sensitive to sample size, thus larger samples yield more accurate results.

\section{Data collection}

Paper-based, structured questionnaires were administered to obtain the data, as this allows for the measurement of a number of constructs using a large sample. It also makes it possible to distribute the questionnaires in a short space of time (Zikmund et al. 2017). The questionnaire commenced with a brief introduction to the study, followed by a consent form that outlined the ethical aspects of the study, including its risks and benefits, maintaining anonymity and confidentiality, being able to withdraw without any consequences and the storage of data.

The second section of the questionnaire asked respondents three screening questions: (1) Are you between the ages of 18 and 25 years, (2) Do you have a social media profile on any social media site? and (3) Have you seen an online comment or review about a brand in the past 6 months? If the respondent answered 'Yes' to all three screening questions, they could complete the rest of the questionnaire.

The third section of the questionnaire was divided into three subsections: Section A pertained to demographics, Section B pertained to general social media behaviour and Section $C$ used a five-point Likert-type scale to measure the five constructs of the study: source credibility, argument quality, information usefulness, information adoption and brand love. Respondents were asked to rate the extent to which they agreed with the statements, where 1 equalled 'strongly disagree' and 5 equalled 'strongly agree'. The scales in Section C were adopted from Sirithanaphonchai (2017), Teng et al. (2014) and Vernuccio et al. (2015). The data were collected over a 4-week period by field workers who handed out the questionnaires in public areas in the selected city. They informed respondents of the reason for the study, as well as their rights, assuring them of confidentiality and anonymity. Ethical clearance for the study was obtained from the University of Joahnnesburg's ethics committee.

\section{Data analysis and results}

Once the data had been collected, they were captured, coded and cleaned using SPSS version 25, yielding 284 usable questionnaires. To analyse the results from Section A (demographics) and Section B (general social media behaviour), descriptive statistics were used. Confirmatory factor analysis (CFA) was used to test the validity of the constructs obtained from previously developed scales through convergent and discriminant validity. The reliability 
of the constructs was tested using Cronbach's alpha and composite reliability. The conceptual model was then tested using structural equation modelling and the hypotheses were analysed using path modelling in AMOS version 25.

The 284 questionnaires were tested for normality using skewness and kurtosis, for which the data needed to lie between negative two and positive two and negative seven and positive seven, respectively (Pallant 2016). After performing the analysis on SPSS, it emerged that the data were normally distributed and falled within the above parameters. Therefore, parametric tests could be conducted.

The next section describes the process that was followed and the criteria that were considered to conduct the CFA.

To conduct CFA, a minimum sample size of 150 is required (Ainur et al. 2017). This study met this criterion as the sample comprised 284 respondents. Five data points for each scale item were used. Bartlett's test of sphericity should be significant $(p \leq 0.000)$ and the KMO value should be greater than 0.6 (Pallant 2016). For this study, the results of Bartlett's test proved significant and the KMO value was greater than 0.6. Thus, the criteria for sampling adequacy were met and the CFA was conducted. The CFA resulted in a five-factor solution: only eigenvalues above 1 were extracted and coefficients below 0.3 were excluded from the analysis. The five factors were (1) source credibility, (2) argument quality, (3) information usefulness, (4) information adoption and (5) brand love.

To test reliability, Cronbach's alpha and composite reliability tests were conducted. Cronbach's alpha and composite reliability values should be greater than or equal to 0.7 (Hair et al. 2015). As indicated in Table 1, all the constructs were proven to be reliable because all the values were greater than 0.7 . The validity of the constructs was also determined using convergent and discriminant validity. Shrestha (2021) stated that for convergent validity, the average variance extracted (AVE) should be greater than 0.5. Based on the results in Table 1, all indicators were above the satisfactory level of 0.5 and could therefore be regarded as valid.

To measure discriminant validity, an inter-construct correlation matrix was used by calculating the square roots of the AVE. The first requirement for discriminant validity is for constructs to load high on themselves (Rönkkö \& Cho 2020). As indicated in Table 2, all the constructs were loaded at the highest value, namely 1 . The second requirement is to compare the square root of the AVE of each construct with each latent construct correlation. The square root of the AVE should be greater than its highest correlation with any other construct (Hair et al. 2015; Shrestha 2021). As shown in Table 2 , discriminant validity was confirmed.

\section{Descriptive results and demographic profile}

The descriptive statistics were analysed based on the data obtained from Sections A and B of the questionnaire. The
TABLE 1: Factor analysis results.

\begin{tabular}{|c|c|c|c|c|}
\hline Items or factors & Factor loadings & AVE & CR & Cronbach's $\alpha$ \\
\hline Source credibility & & 0.514 & 0.808 & 0.805 \\
\hline SC1 & 0.715 & - & - & - \\
\hline SC2 & 0.700 & - & - & - \\
\hline SC3 & 0.784 & - & - & - \\
\hline SC4 & 0.664 & - & - & - \\
\hline Argument quality & & 0.563 & 0.886 & 0.894 \\
\hline AQ1 & 0.750 & - & - & - \\
\hline $\mathrm{AQ2}$ & 0.716 & - & - & - \\
\hline AQ3 & 0.722 & - & - & - \\
\hline AQ4 & 0.758 & - & - & - \\
\hline AQ5 & 0.756 & - & - & - \\
\hline AQ6 & 0.750 & - & - & - \\
\hline Information usefulness & & 0.637 & 0.896 & 0.894 \\
\hline IU1 & 0.743 & - & - & - \\
\hline IU2 & 0.831 & - & - & - \\
\hline IU3 & 0.808 & - & - & - \\
\hline IU4 & 0.823 & - & - & - \\
\hline IU5 & 0.771 & & & \\
\hline eWOM adoption & & 0.549 & 0.879 & 0.877 \\
\hline IA1 & 0.709 & - & - & - \\
\hline IA2 & 0.639 & - & - & - \\
\hline IA3 & 0.737 & - & - & - \\
\hline IA4 & 0.719 & - & - & - \\
\hline IA5 & 0.799 & - & - & - \\
\hline IA6 & 0.827 & - & - & - \\
\hline Brand love & & 0.708 & 0.923 & 0.922 \\
\hline BL1 & 0.714 & - & - & - \\
\hline BL2 & 0.879 & - & - & - \\
\hline BL3 & 0.859 & - & - & - \\
\hline BL4 & 0.909 & - & - & - \\
\hline BL5 & 0.832 & - & - & - \\
\hline
\end{tabular}

TABLE 2: Inter-construct correlation matrix

\begin{tabular}{lccccc}
\hline Research constructs & SC & AQ & IU & IA & BL \\
\hline SC & 1 & - & - & - & - \\
AQ & $0.570^{*}$ & 1 & - & - & - \\
IU & $0.359^{*}$ & $0.480^{*}$ & 1 & - & - \\
IA & $0.264^{*}$ & $0.426^{*}$ & $0.504^{*}$ & 1 & - \\
BL & $0.130^{*}$ & $0.116^{*}$ & $0.089^{*}$ & $0.067^{*}$ & 1 \\
\hline
\end{tabular}

$\mathrm{AQ}$, argument quality; BL, brand love; IA, eWOM adoption; IU, information usefulness; SC, Source credibility.

*, denotes that the correlation is significant ( $p$-value is 0.01 ).

results from Section A indicated that there was an almost equal split between males and females who completed the questionnaire, at $45.3 \%$ and $54.4 \%$, respectively. Of the Generation $Z$ consumers who were sampled, most had a university degree $(46.2 \%)$, followed by a high school certificate $(30.8 \%)$ and a diploma $(17.1 \%)$.

Section B of the questionnaire asked respondents about their social media behaviour. The results showed that $35.2 \%$ of the respondents read online reviews and comments on Facebook, closely followed by $31 \%$ who read them on Instagram. Of those who read online reviews and comments, $60.9 \%$ do so daily and $20.4 \%$ do so four to five times a week. Of those who read online reviews and comments, $34.2 \%$ had been using their social media site to read them for 4-6 years, followed by $30.6 \%$ who had been reading them from 1 to 3 years. Respondents were then asked about which brand they read 
TABLE 3: Hypotheses test results.

\begin{tabular}{lcccl}
\hline $\begin{array}{l}\text { Hypothesised } \\
\text { relationship }\end{array}$ & Hypotheses & Path coefficient & $p$ & $\begin{array}{l}\text { Supported or not } \\
\text { supported }\end{array}$ \\
\hline $\mathrm{SC} \rightarrow \mathrm{IU}$ & $\mathrm{H} 1$ & 0.220 & 0.018 & Not supported \\
$\mathrm{AQ} \rightarrow \mathrm{IU}$ & $\mathrm{H} 2$ & 0.530 & $*$ & Supported \\
$\mathrm{IU} \rightarrow \mathrm{IA}$ & $\mathrm{H} 3$ & 0.740 & $*$ & Supported \\
$\mathrm{IA} \rightarrow \mathrm{BL}$ & $\mathrm{H} 4$ & 0.270 & $*$ & Supported \\
\hline
\end{tabular}

$\mathrm{AQ}$, argument quality; $\mathrm{BL}$, brand love; IA, eWOM adoption; IU, information usefulness; $\mathrm{SC}$ Source credibility.

$*$, denotes that the correlation is significant ( $p$-value is 0.01 ).

the most online reviews and to keep this brand in mind when answering Section C. These brands included Samsung, Apple, Huawei and Netflix. The results of Section C were then analysed.

\section{Structural equation modelling results}

After completing the CFA, structural equation modelling was conducted to assess the proposed conceptual model. The results indicated a good fit between the data and the model: $\mathrm{CMIN} / \mathrm{DF}=2.392, \mathrm{GFI}=0.835, \mathrm{AGFI}=0.803, \mathrm{RMSEA}=0.070$, $\mathrm{NFI}=0.859, \mathrm{TLI}=0.903$. The hypotheses were then examined and analysed using path analysis in AMOS version 25. Fan et al. (2016) explained that path coefficients indicate the strength between the latent constructs, thus a higher value infers a stronger relationship. $P$-values were also analysed to determine whether or not the hypotheses could be supported. $P$-values marked with an asterisk (*) denote the corresponding significance level. A summary of the hypotheses test results is provided in Table 3.

\section{Discussion}

Overall, the results indicated that three of the four hypotheses could be accepted. Source credibility was shown to have an insignificant effect on information usefulness $(\beta=0.220$, $p=0.018)$. This finding disproved most prior studies, including those of Erkan and Evans (2016) and O'Reilly et al. (2016), who demonstrated that source credibility was essential to information usefulness. Conversely, argument quality was proven to have a positive, significant influence on information usefulness $(\beta=0.530, p=0.01)$. This finding was in line with those of Charo et al. (2015) and Hussain et al. (2016), who stated that consumers who perceive eWOM to be of a higher quality find it more useful and relevant to their needs.

It is evident from the results that South African Generation $Z$ consumers' do not perceive the credibility of the source as being important to their perception of the usefulness of the information obtained from eWOM reviews. This suggests that the knowledge, expertise, reliability and experience of the source does not influence Generation $Z$ consumers' perception of the information usefulness of a brand. Therefore, marketers who target Generation $Z$ consumers in South Africa should not concern themselves with the credibility of the source used to market a brand, but rather with the type of information shared. Information perceived as complete, comprehensive, correct, accurate and reliable increased argument quality, as demonstrated by the findings.
Higher perceived argument quality of eWOM reviews leads to the perception that the information is useful. Information perceived as useful is more likely to be adopted (Erkan \& Evans 2016; Hussain et al. 2016; Moran \& Muzellec 2017). The results of this study confirm that relationship, as information usefulness had a strong, significant, positive relationship with eWOM adoption $(\beta=0.740, p=0.01)$. Information is perceived as useful if eWOM reviews are valuable, informative and helpful. Lastly, it was discovered that eWOM adoption had a significant, positive relationship with brand love; however, the relationship was weak $(\beta=0.270$, $p=0.01$ ). Brand love was determined by whether the brand made respondents feel good, awesome and happy. It was evident from the findings of this study that eWOM adoption had a weak effect on whether South African Generation $Z$ consumers loved their brands. This finding presents new insights into the influence of eWOM on brand love, as prior studies on the topic are scant.

\section{Recommendations}

The study's findings indicate that, overall, eWOM adoption influences South African Generation Z consumers, especially if there is high perceived argument quality, which increases the perceived usefulness of the information and thus the adoption of eWOM. Marketers can therefore harness the power of eWOM and devise strategies to target Generation $Z$ consumers in South Africa more effectively. Recommended practices are listed here:

- using Facebook and Instagram, as these are the preferred social networks amongst Generation $Z$ consumers in South Africa. Marketers should refer to these social networks to identify and target Generation $Z$ consumers

- sharing comprehensive, correct, accurate and reliable content about international brands, including large technology brands such as Samsung, Apple, Huawei and Netflix

- encouraging the sharing of quality content (eWOM reviews) often, as most Generation $Z$ consumers in South Africa read eWOM reviews daily. Marketers can use influencer marketing (Dunkley 2017) to encourage influencers with prior experience of a brand to share accurate, useful and timely content to enhance perceptions of good argument quality to increase the usefulness of the information conveyed.

Despite the weak relationship between eWOM adoption and brand love, the following is recommended:

- marketers can encourage influencers to share content that depicts them as feeling good and happy whilst using the brand to enhance the authenticity of the information conveyed. As suggested by Hanbury (2019) and Djafarova and Bowes (2021), Generation $Z$ consumers avoid marketer-generated content, preferring authentic and genuine content generated by other consumers. Having authentic content increases the perceived argument quality of the eWOM. Better argument quality infers that information is useful and relevant, thereby encouraging 
Generation Z consumers to adopt eWOM. For some, this will positively affect their love of a brand.

\section{Limitations and future directions}

As with all research, this study has limitations. Firstly, the sample was limited to one city in South Africa and so, it is not representative of all South Africans. Future research should consider geographic areas in South Africa that have the secondand third-highest internet usage rates in the country. Secondly, because of the quantitative nature of the study, gaining an indepth understanding of why eWOM has a limited effect on brand love could not be achieved. Future studies could use a more qualitative approach to build on the existing study and so gain a deeper understanding of Generation $Z$ consumers' perceptions of eWOM and brand love. Thirdly, this study focussed on brand love in general and respondents were able to select any brand. Future studies of brand love could be applied to specific industries such as the fashion and beauty industry, where brand love is more apparent.

\section{Conclusion}

This study investigated the influence of eWOM on brand love amongst Generation Z consumers in South Africa. It was discovered that Generation $Z$ consumers adopt information conveyed through eWOM reviews provided there is high perceived argument quality. Despite their willingness to adopt the eWOM reviews, the findings revealed a positive yet weak relationship between eWOM and brand love. Marketers could use the results obtained from this study to encourage eWOM by using influencer marketing. Influencer marketing can enhance perceived argument quality, information usefulness and information adoption of eWOM, which will, to some extent, positively influence brand love amongst Generation $Z$ consumers in South Africa.

\section{Acknowledgements Competing interests}

The author has no financial or personal relationships that may have inappropriately influenced the writing of this article.

\section{Author's contributions}

The author has met all the criteria for authorship, in accordance with the authorship policy and author contribution policy statement.

\section{Ethical considerations}

Approval to conduct the study was obtained from the School of Consumer Intelligence and information systems ethics committee at the University of Johannesburg, ethical clearance code: 2019SCiiS14.

\section{Funding information}

The author received no financial support for the research, authorship, and/or publication of this article.

\section{Data availability}

The data collected for this study remains under encrypted, password-protected files with the author. The data that support the findings of this study are available from the author upon reasonable request.

\section{Disclaimer}

The views expressed in this article are the author's own and not an official position of the institution or funder.

\section{References}

Ainur, A.K., Sayang, M.D., Jannoo, Z. \& Yap, B.W., 2017, 'Sample size and non-normality effects on goodness of fit measures in structural equation models', Pertanika Journal of Science \& Technology 25(2), 575-586.

Alanko, P.J., 2018, 'Mapping eWOM effectiveness for Generation Z consumers: An integrative approach', Master's thesis, Dept. of Marketing, Hanken School of Economics, Helsinki.

Amadeo, K., 2020, Emerging market countries and their five defining characteristics, viewed 05 March 2021, from https://www.thebalance.com/what-are-emergingmarkets-3305927.

Amankwah-Amoah, J., Boso, N. \& Debrah, Y.A., 2018, 'Africa rising in an emerging world: An international marketing perspective', International Marketing Review 35(4), 550-559. https://doi.org/10.1108/IMR-02-2017-0030

Aregbeshola, R.A., 2018, 'The machination of foreign direct investment flow to emerging markets: A focus on Africa', African Journal of Economic and Management Studies 9(4), 430-448. https://doi.org/10.1108/AJEMS-12-2017-0313

Asongu, S., Akpan, U.S. \& Isihak, S.R., 2018, 'Determinants of foreign direct investment in fast-growing economies: Evidence from the BRICS and MINT countries', Financial Innovation 4(1), 26. https://doi.org/10.1186/s40854-018-0114-0

Ayuni, R.F., 2019, 'The online shopping habits and e-loyalty of Gen Z as natives in the digital era', Journal of Indonesian Economy and Business 34(2), 168-184. https:// doi.org/10.22146/jieb.39848

Bagozzi, R.P., Batra, R. \& Ahuvia, A., 2017, 'Brand love: Development and validation of a practical scale', Marketing Letters 28(1), 1-14. https://doi.org/10.1007/s11002 016-9406-1

Bao, Z. \& Haung, T., 2018, 'Exploring stickiness intention of B2C online shopping malls: A perspective from information quality', International Journal of Web Information Systems 14(22), 177-192. https://doi.org/10.1108/IJWIS-10-2017-0071

Bhandari, M., Rodgers, S. \& Pan, P.L., 2021, 'Brand feedback to negative eWOM messages: Effects of stability and controllability of problem causes on brand
attitudes and purchase intentions', Telematics and Informatics58(1), 1-14. attitudes and purchase intentions', Telem
$\mathrm{https} / / /$ doi.org/10.1016/j.tele.2020.101522

Bıçakcıoğlu, N., İpek, İ. \& Bayraktaroğlu, G., 2018, 'Antecedents and outcomes of brand love: The mediating role of brand loyalty', Journal of Marketing Communications 24(8), 863-877. https://doi.org/10.1080/13527266.2016.1244108

Bigne, E., Andreu, L., Perez, C. \& Ruiz, C., 2019, 'Brand love is all around: Loyalty behaviour, active and passive social media users', Current Issues in Tourism23(13), 1-18. https://doi.org/10.1080/13683500.2019.1631760

Bruns, I., 2018, “Trust" and "perceived authenticity" in social media driven influencer marketing and their influence on intentions-to-buy of 18 to 24-year-olds in Ireland', PhD thesis, Dublin Business School.

Charo, N., Sharma, P., Shaikh, S., Haseeb, A.\& Sufya, M.Z., 2015, 'Determining the impact of eWOM on brand image and purchase intention through adoption of online opinions', International Journal of Humanities and Management Sciences 3(1), 41-46.

Chetty, K., Qigui, L., Gcora, N., Josie, J., Wenwei, L. \& Fang, C., 2018, 'Bridging the digital divide: Measuring digital literacy', Economics: The Open-Access, OpenAssessment E-Journal 12(23), 1-20. https:///doi.org/10.5018/economics-ejournal. ja.2018-23

Chong, A.Y.L., Khong, K.W., Ma, T., McCabe, S. \& Wang, Y., 2018, 'Analyzing key influences of tourists' acceptance of online reviews in travel decisions', Internet Research 28(3), 564-586. https://doi.org/10.1108/IntR-05-2017-0212

Corporate Finance Institute, 2021, What is an emerging market economy? viewed 05 March 2021, from https://corporatefinanceinstitute.com/resources/knowledge/ economics/emerging-market-economy/.

Cronje, A., Jacobs, B. \& Retief, A., 2016, 'Black urban consumers' status consumption of clothing brands in the emerging South African market', International Journal of Consumer Studies 40(6), 754-764. https://doi.org/10.1111/ijcs.12293

Cruz, M.M.M.D., 2016, 'Generation Z: Influencers of decision-making processes: The influence of WOM and peer interaction in the decision-making process', PhD thesis, Universidade Catolica Portuguesa.

Davis, F.D., 1989, 'Perceived usefulness, perceived ease of use and user acceptance of information technology', MIS Quarterly 13(3), 319-340. https://doi.org/10.2307/ 249008

Debb, S.M., Schaffer, D.R. \& Colson, D.G., 2020, 'A reverse digital divide: Comparing information security behaviours of generation $\mathrm{Y}$ and generation $\mathrm{Z}$ adults', International Journal of Cybersecurity Intelligence \& Cybercrime 3(1), 42-55. 
Deloitte, 2014, The Deloitte consumer review Africa: A 21st century review, viewed 15 May 2020, from https://www2.deloitte.com/content/dam/Deloitte/ng/
Documents/consumer-business/the-deloitte-consumer-review-africa-a-21stDocuments/consum

Diaz, J., 2019, How is business responding to a generation who prefers loyalty to novelty? viewed 15 May 2020, from https://www.bizcommunity.com/ Article/196/20/190981.html.

Djafarova, E. \& Bowes, T., 2021, “'Instagram made me buy it": Generation Z impulse purchases in fashion industry', Journal of Retailing and Consumer Services59(1), 1-9. https://doi.org/10.1016/j.jretconser.2020.102345

Duffett, R.G., 2017, 'Influence of social media marketing communications on young consumers' attitudes', Young Consumers 18(1), 19-39. https://doi.org/10.1108/ YC-07-2016-00622

Duffett, R.G., 2020, 'The YouTube marketing communication effect on cognitive, affective and behavioural attitudes among Generation $Z$ consumers', Sustainability12(12), 1-25. https://doi.org/10.3390/su12125075

Dunkley, L., 2017, 'Reaching Generation Z: Harnessing the power of digital influencers in film publicity', Journal of Promotional Communications 5(1), 30-39.

Erkan, I. \& Evans, C., 2016, 'The influence of eWOM in social media on consumers' purchase intentions: An extended approach to information adoption', Computers in HumanBehaviour 61(1), 47-55. https://doi.org/10.1016/j.chb.2016.03.003

Erkan, I. \& Evans, C., 2018, 'Social media or shopping websites? The influence of eWOM (6.tions 24(6), 617-632. https://doi.org/10.1080/13527266.2016.1184706

Euromonitor, 2018, Generation Z: The next wave of consumers, viewed 13 May 2020, from https://blog.euromonitor.com/generation-z-next-wave-consumers/

Fan, Y., Chen, J., Shirkey, G., John, R., Wu, S.R., Park, H. \& Shao, C., 2016, 'Applications of structural equation modeling (SEM) in ecological studies: An updated review', Ecological Processes 5(1), 1-12. https://doi.org/10.1186/s13717-016-0063-3

Fanoberova, A. \& Kuczkowska, H., 2016, 'Effects of source credibility and information quality on attitudes and purchase intentions of apparel products: A quantitative study of online shopping among consumers in Sweden', Master's thesis, Umeå School of Business and Economics, Umeå.

Ferreira, F. \& Barbosa, B., 2017, 'Consumers' attitude toward Facebook advertising', International Journal of Electronic Marketing and Retailing 8(1), 45-57. https:// doi.org/10.1504/IJEMR.2017.083552

Florenthal, B., 2019, 'Young consumers' motivational drivers of brand engagement behaviour on social media sites', Journal of Research in Interactive Marketing 13(1), 351-391. https://doi.org/10.1108/JRIM-05-2018-0064

Fourie, J., 2017, Why \#DataMustFall, viewed 11 May 2020, from https://www.fin24. com/Finweek/Opinion/why-datamustfall-20170825.

Gomo, C., 2019, 'Government transfers, income inequality and poverty in South Africa', International Journal of Social Economics 46(12), 1349-1368. https://doi. org/10.1108/IJSE-09-2018-0458

Hair, J.F., Black, W.C., Babin, B.J.\&Anderson, R.E., 2015, Multivariate data analysis, 7th edn., Pearson Education, Noida.

Hanbury, M., 2019, Gen Z is leading an evolution in shopping that could kill brands as we know them, viewed 13 May 2020, from https://www.businessinsider.com/ gen-z-shopping-habits-kill-brands-2019-7?IR=T.

Hodgson, A.N., 2018, Generation Z, the next wave of consumers, viewed 03 March 2021, from https://blog.euromonitor.com/generation-z-next-wave-consumers/.

Huang, C.C., 2017, 'The impacts of brand experiences on brand loyalty: Mediators of brand love and trust', Management Decision 55(5), 915-934. https://doi. brand love and trust', Managen
org/10.1108/MD-10-2015-0465

Hussain, S., Ahmed, W., Jafar, R.M.S., Rabnawaz, A., Akhtar, H. \& Jianzhou, Y., 2016, 'Electronic word of mouth communications and consumer's information adoption on the Internet', IEEE International Conference on Computer Communication and the Internet (ICCCI), Wuhan, October 13-15, 2016, pp. 493-497.

In'nami, Y. \& Koizumi, R., 2013, 'Review of sample size for structural equation models in second language testing and learning research: A Monte Carlo approach' International Journal of Testing 13(4), 329-353. https://doi.org/10.1080/1530505 8.2013 .806925

Islam, J.U. \& Rahman, Z., 2016, 'Examining the effects of brand love and brand image on customer engagement: An empirical study of fashion apparel brands', Journal of Global Fashion Marketing 7(1), 45-59. https://doi.org/10.1080/20932685.2015. 1110041

Ismagilova, E., Slade, E., Rana, N.P. \& Dwivedi, Y.K., 2019, 'The effect of characteristics of source credibility on consumer behaviour: A meta-analysis', Journal of Retailing and Consumer Services 53(1), 1-20. https://doi.org/10.1016/j.jretconser.2019.01.005

Ismail, A.R. \& Melewar, T.C., 2015, 'Binational study of the impact of brand image, brand personality and brand love on word of mouth: The case of fashion brands in UK and Switzerland', in L. Robinson, Jr. (eds.), Marketing dynamism \& sustainability: Things change, things stay the same.... Developments in marketing science: Proceedings of the Academy of Marketing Science, Springer, Cham. https://doi. org/10.1007/978-3-319-10912-1_151

Jenkins, R., 2019, Marketing to Generation Z? Here's what you need to know, viewed 15 May 2020, from https://www.inc.com/ryan-jenkins/marketing-to-generationz-heres-what-you-need-to-know.html.

Jordaan, L., 2019, Brand me, Gen Z: Marketing from millenials to centennials, viewed 02 March 2021, from https://themediaonline.co.za/2019/08/brand-me-gen-zmarketing-from-millennials-to-centennials/.

Karjaluoto, H., Munnukka, J. \& Kiuru, K., 2016, 'Brand love and positive word of mouth: The moderating effects of experience and price', Journal of Product \& Brand Management 25(6), 527-537. https://doi.org/10.1108/JPBM-03-2015-0834
Kazmi, S.H.A. \& Khalique, M., 2019, 'Brand experience and mediating roles of brand love, brand prestige and brand trust', Market Forces 14(2), 78-98.

Kemp, S., 2019, Digital South Africa, viewed 15 May 2020, from https://datareportal. com/reports/digital-2019-south-africa.

Killian, D., Kabanda, S. \& Kilian, D., 2017, 'Mobile payments in South Africa: Middle income earners' perspective', Proceedings for the 21st Pacific Asia Conference on Information Systems, Langkawi, Kedah, October 19, 2017, pp. 1-13.

Kim, A.J. \& Johnson, K.K., 2016, 'Power of consumers using social media: Examining the influences of brand-related user-generated content on Facebook', Computer in Human Behaviour 58(1), 98-108. https://doi.org/10.1016/j.chb.2015.12.047

Kowalczyk, C.M. \& Pounders, K.R., 2016, 'Transforming celebrities through social media: The role of authenticity and emotional attachment', Journal of Product \& Brand Management 25(4), 345-356. https://doi.org/10.1108/JPBM-09-2015-0969

Kyriazos, T.A., 2018, 'Applied psychometrics: Sample size and sample power considerations in factor analysis (EFA, CFA) and SEM in general', Psychology 9(8), 2207-2227. https://doi.org/10.4236/psych.2018.98126

Loveland, E., 2017, 'Instant generation', Journal of College Admission 235(1), 34-38.

Malapane, T.A., 2019, 'A risk analysis of e-commerce: A case of South African online shopping space', 2019 Systems and Information Engineering Design Symposium (SIEDS), IEEE, April 26, Charlottesville, VA, pp. 1-6.

Masekesa, F., 2020, Nigeria, South Africa and Kenya dominate the e-commerce industry in sub-Saharan Africa, viewed 11 May 2020, from http://www. theasianbanker.com/updates-and-articles/nigeria, -south-africa-and-kenyadominate-the-e-commerce-industry-in-sub-saharan-africa.

Masipa, T.S., 2018, 'The relationship between foreign direct investment and economic growth in South Africa: Vector error correction analysis', Acta Commercii18(1), 1-8. https://doi.org/10.4102/ac.v18i1.466

Mehta, R. \& Dixit, G., 2016, 'Consumer decision making styles in developed and developing markets: A cross-country comparison', Journal of Retailing and Consumer Services 33(1), 202-208. https://doi.org/10.1016/j.jretconser.2016.09.002

Melewar, T. C., Nguyen, B., Merrilees, B., Garg, R., Mukherjee, J., Biswas, S. \& Kataria, A., 2015, 'An investigation of antecedents and consequences of brand love in India', Asia-Pacific Journal of Business Administration, 7(3), 174-196.

Meyer, D.F. \& Habanabakize, T., 2018, 'An analysis of the relationship between foreign direct investment (FDI), political risk and economic growth in South Africa' Business \& Economic Horizons 14(4), 789-817. https://doi.org/10.15208/ beh.2018.54

Mody, M. \& Hanks, L., 2018, Consumption authenticity in the age of the sharing economy: The key to creating loyal customers who love your brand, viewed 15 May 2020, from https://open.bu.edu/bitstream/handle/2144/26399/Fall\%20 $2017 \% 20$ Conference $\% 20$ Final $\% 20$ Submission $\% 20-\% 20$ Mody $\% 20 \& \% 20$ Hanks\%20-\%20081617.pdf?sequence=1.

Moran, G. \& Muzellec, L., 2017, 'eWOM credibility on social networking sites: A framework', Journal of Marketing Communications 23(2), 149-161. https://doi.or $\mathrm{g} / 10.1080 / 13527266.2014 .969756$

Mou, J., Cohen, J., Dou, Y. \& Zhang, B., 2017, 'Predicting buyers' repurchase intentions in cross-border e-commerce: A valence framework perspective', Proceedings of the European conference for information systems, Braga, June 5-10, 2017, pp. 2382-2394.

Munsch, A., 2021, 'Millennial and Generation Z digital marketing communication and advertising effectiveness: A qualitative exploration', Journal of Global Scholars of Marketing Science31(1), 10-29. https://doi.org/10.1080/21639159.2020.1808812

Narangajavana, Y., Fiol, L.J.C., Tena, M.Á.M., Artola, R.M.R. \& García, J.S., 2017, ??The influence of social media in creating expectations: An empirical study for a tourist influence of social media in creating expectations: An empirical study for a tourist
destination', Annals of Tourism Research 65(1), 60-70. https://doi.org/10.1016/j. destination', Annals
annals.2017.05.002

Ndyave, Z.C. \& Kyobe, M., 2017, 'Factors that influence mobile bully-victim behaviour on social media: The case of Facebook', Journal of Advances in Information Technology 8(4), 230-233. https://doi.org/10.12720/jait.8.4.230-233

O’Reilly, K., MacMillan, A., Mumuni, A.G. \& Lancendorfer, K.M., 2016, 'Extending our understanding of eWOM impact: The role of source credibility and message relevance', Journal of Internet Commerce 15(2), 77-96. https://doi.org/10.1080/1 relevance', Journal of Intern

Ordun, G., 2015, 'Millennial (Gen Y) consumer behaviour, their shopping preferences and perceptual maps associated with brand loyalty', Canadian Social Science 11(4), 40-55. https://doi.org/10.3968/\%25x

Pallant, J., 2016, SPSS survival manual, McGrawHill Education, London.

Pavlić, I. \& Vukić, M., 2019, 'Decision-making styles of Generation Z consumers in Croatia', Ekonomska Misao i Praksa 1(1), 79-95. https://doi.org/10.1080/153328 61.2016 .1143215

Peyper, L., 2017, SA economy no longer stable-Fragile states index, viewed 15 May 2020, from https://www.fin24.com/Economy/sa-economy-no-longerstable-fragile-states-index-20170625.

Phung, M.T., Ly, P.T.M., Nguyen, T.T. \& Nguyen-Thanh, N., 2020, 'An FsQCA investigation of eWOM and social influence on product adoption intention', Journal of Promotion Management26(5), 726-747. https://doi.org/10.1080/10496491.2020.1729318

Poushter, J., Bishop, C.\& Chwe, H., 2018, Social media use continues to rise in developing countries but plateaus across developed ones, Pew Research Center, viewed 16 May 2020, from http://medienorge.uib.no/files/Eksterne_pub/PewResearch-Center_Global-Tech-Social-Media-Use_2018.06.19.pdf.

Prasad, S., Gupta, I.C. \& Totala, N.K., 2017, 'Social media usage, electronic word of mouth and purchase-decision involvement', Asia-Pacific Journal of Business Administration 9(2), 134-145. https://doi.org/10.1108/APJBA-06-2016-0063 
Priporas, C.V., Stylos, N. \& Fotiadis, A.K., 2017, 'Generation Z consumers' expectations of interactions in smart retailing: A future agenda', Computers in Human Behaviou 77(1), 374-381. https://doi.org/10.1016/j.chb.2017.01.058

Rahmi, Y., Sekarasih, L. \& Sjabadhyni, B., 2016, 'The influence of beauty vlog on perceived source credibility and purchase intention', Makara Hubs-Asia 20(2), 13-23. https://doi.org/10.7454/mssh.v21i1.3496

Riivits-Arkonsuo, I. \& Leppiman, A., 2015, 'Young consumers and their brand love', International Journal of Business and Social Research 5(10), 33-44.

Rizwan, M., Akbar, I., Muqtadir, A., Shafique, U., Zia, H., Naseer, W. \& Amin, S.A., 2013 'Impact of brand switching, brand credibility, customer satisfaction and service quality on brand loyalty', IOSR Journal of Business and Management 1(1), 12-20.

Rönkkö, M. \& Cho, E., 2020, 'An updated guideline for assessing discriminant validity', Organizational Research Methods. Online first. https://doi. org/10.1177/1094428120968614

Ronnie, L., 2018, Should we be worried about Generation Z joining the workforce? Here's why not, viewed 13 May 2020, from https://www.gsb.uct.ac.za/fogenerationz-workforce.

Ruiz-Mafe, C. \& Veloutsou, C., 2017, 'Information flow and WOM in social media and online communities', Online Information Review 41(7), 902-904. https://doi. org/10.1108/OIR-09-2017-0255

Saksiriruthai, S., 2019, 'Emerging markets: Modern conceptual principles and characteristics', Actual Economy: Local Solutions for Global Challenges: 20th International Conference, ACE2019 proceedings, Edinburgh, November 18-21, 2019, pp. 440-446.

Shamhuyenhanzva, R.M., Van Tonder, E., Roberts-Lombard, M. \& Hemsworth, D. 2016, 'Factors influencing Generation Y consumers' perceptions of eWOM credibility: A study of the fast-food industry', The International Review of Retail, Distribution and Consumer Research 26(4), 435-455. https://doi.org/10.1080/09 593969.2016.1170065

Shan, Y. \& King, K.W., 2015, 'The effects of interpersonal tie strength and subjective norms on consumers' brand-related eWOM referral intentions', Journal of Interactive Advertising 15(1), 16-27. https://doi.org/10.1080/15252019.2015.1016636

Shrestha, N., 2021, 'Factor analysis as a tool for survey analysis', American Journal of Applied Mathematics and Statistics9(1), 4-11. https://doi.org/10.12691/ajams-9-1-2

Sirithanaphonchai, J., 2017, 'Identifying consumers' information adoption criteria on various online consumer review platforms: A case of Thai hospitality factor', PhD thesis, Brunel University, London.

Skeldon, P., 2019, Generation Z want to see authenticity in their fashion brands Whatever that means..., viewed 15 May 2020, fromhttps://internetretailing.net/ Whatever that means..., viewed 15 May 2020, fromhttps://internetretailing.net/
brands/brands/generation-z-want-to-see-authenticity-in-their-fashion-brands-whatever-that-means--20453.

Statista, 2018, Online shopping reach among Generation Z internet users worldwide as of 4 th quarter 2018 , by device, viewed 12 May 2020 from https://www.statista. of 4 th quarter 2018, by device, viewed 12 May 2020, from https://www.s
com/statistics/266955/gen-z-online-shopping-reach-by-device-worldwide

Statista, 2020, Number of Facebook users in South Africa from 2017-2023, viewed 15 May 2020, from https://www.statista.com/statistics/558248/number-offacebook-users-in-south-africa/.

StatsSA, 2018, General household survey - 2018, viewed 13 May 2020, from http:// www.statssa.gov.za/publications/P0318/P03182018.pdf.

Stats SA, 2019a, Economy dodges recession as GDP climbs 1.3, viewed 16 May 2020, from http://www.statssa.gov.za/?p=12471.

Stats SA, 2019b, Youth graduate unemployment rate, viewed 16 May 2020, from http://www.statssa.gov.za/?p=12121.

Sussman, S.W. \& Siegal, W.S., 2003, 'Informational influence in organizations: An integrated approach to knowledge adoption', Information Systems Research 14(1), 47-65. https://doi.org/10.1287/isre.14.1.47.14767

Tandwa, L., 2020, Ramaphosa promises free data for low-income South Africans, viewed 16 May 2020, from https://www.news24.com/SouthAfrica/News/ ramaphosa-promises-free-data-for-low-income-south-africans-20200213.

Taute, H.A., Sierra, J.J., Carter, L.L. \& Maher, A.A., 2017, 'A sequential process of brand tribalism, brand pride and brand attitude to explain purchase intention: A crosscontinent replication study', Journal of Product \& Brand Management 26(3) 239-250. https://doi.org/10.1108/JPBM-08-2016-1289
Teng, S., Wei Khong, K., Wei Goh, W. \& Yee Loong Chong, A., 2014, 'Examining the antecedents of persuasive eWOM messages in social media', Online Information Review 38(6), 746-768. https://doi.org/10.1108/OIR-04-2014-0089

Thomas, M.R., Kavya, V. \& Monica, M., 2018, 'Online website cues influencing the purchase intention of Generation Z mediated by trust', Indian Journal of Commerce and Management Studies 9(1), 13-23. https://doi.org/10.18843/ ijcms/v9i1/03

Thompson, R., 2017, Capturing the Generation Z opportunity, viewed 14 May 2020, from https://www.bizcommunity.com/Article/196/347/168583.html.

Tong, X., Bao, H. \& Chong, A.Y.L., 2016, 'Predicting adoption of location-based social media service in travel decisions', International Journal of Mobile Communications 14(6), 539-552. https://doi.org/10.1504/IJMC.2016.079298

Tsagkanos, A., Siriopoulos, C. \& Vartholomatou, K., 2019, 'Foreign direct investment and stock market development: Evidence from a "new" emerging market', Journa of Economic Studies 46(1), 55-70. https://doi.org/10.1108/JES-06-2017-0154

Tseng, S.Y. \& Wang, C.N., 2016, 'Perceived risk influence on dual-route information adoption processes on travel websites', Journal of Business Research 69(6), 22892296. https://doi.org/10.1016/j.jbusres.2015.12.044

Verma, P., 2021, 'The effect of brand engagement and brand love upon overall brand equity and purchase intention: A moderated-mediated model', Journal of Promotion Management27(1),103-132.https://doi.org/10.1080/10496491.2020. 1809591

Vernuccio, M., Pagani, M., Barbarossa, C. \& Pastore, A., 2015, 'Antecedents of brand love in online network-based communities: A social identity perspective', Journa of Product \& Brand Management 24(7), 706-719. https://doi.org/10.1108/JPBM12-2014-0772

Viertola, W., 2018, 'To what extent does YouTube marketing influence the consume behaviour of a young target group?', PhD thesis, Lund University School of Economics and Management, Lund.

Wang, Y., 2016, 'Information adoption model: A review of the literature', Journal of Economics and Business Management 4(11), 618-622. https://doi.org/10.18178/ joebm.2016.4.11.462

World Bank, 2019, The World Bank in South Africa, viewed 15 May 2020, from https:// www.worldbank.org/en/country/southafrica/overview.

World Network, 2019, United Nations: Global FDI flows fell by 19\% last year, viewed 05 March 2021, from https://www.twn.my/title2/wto.info/2019/ti190107.htm.

Yang, F.X., 2017, 'Effects of restaurant satisfaction and knowledge sharing motivation on eWOM intentions: The moderating role of technology acceptance factors', Journal of Hospitality and Tourism Research 41(1), 93-127. https://doi org/10.1177/1096348013515918

Zahra, N., Qayyum, A. \& Rashid, Y., 2019, 'Traveller's empowerment: Travelling website service quality, attitude towards UGC and booking intentions of travellers', Business \& Economic Review 11(4), 35-58. https://doi.org/10.22547/BER/11.4.2

Zeng, C.F. \& Seock, Y.K., 2019, 'Chinese consumers' perceptions toward social media platform for shopping and eWOM intention: A study of WeChat', International Journal of Fashion Design, Technology and Education 12(2), 199-207. https://doi. org/10.1080/17543266.2019.1572230

Zhang, J., Ito, N., Wu, W. \& Li, Z., 2017, 'Exploring travel information adoption on social media in the Chinese context: An extended elm model with users' social presence', International Journal of Marketing and Social Policy 1(1), 41-54. https://doi. org/10.17501/23621044.2017.1105

Zhang, X.J. \& Barnes, C., 2019, 'The suspicious factors in electronic word-of-mouth communication', Journal of Marketing Development and Competitiveness 13(2), 101-115. https://doi.org/10.33423/jmdc.v13i2.2015

Zhitomirsky-Geffet, M. \& Blau, M., 2016, 'Cross-generational analysis of predictive factors of addictive behaviour in smartphone usage', Computers in Human Behaviour 64(1), 682-693. https://doi.org/10.1016/j.chb.2016.07.061

Zhu, D.H., Chang, Y.P. \& Luo, J.J., 2016, 'Understanding the influence of C2C communication on purchase decision in online communities from a perspective of information adoption model', Telematics and Informatics 33(1), 8-16. https://doi. org/10.1016/j.tele.2015.06.001

Zikmund, W.G., D’Alessandro, S., Winzar, H., Lowe, B. \& Babin, B., 2017, Marketing research, Asia-Pacific edition, Cengage, Melbourne. 